\title{
Rapeseed or linseed supplements in grass-based diets: Effects on dairy performance of Holstein cows over 2 consecutive lactations
}

\author{
S. Lerch, ${ }^{\star}$ A. Ferlay, ${ }^{\star}$ D. Pomiès, ${ }^{\star} \dagger$ B. Martin, ${ }^{\star}$ J. A. A. Pires, ${ }^{\star}$ and Y. Chilliard ${ }^{\star 1}$ \\ *INRA, UR1213 Herbivores, F63122 Saint-Genès Champanelle, France \\ †INRA, UE1296 Monts d'Auvergne, F63210 Orcival, France
}

\begin{abstract}
The aim of this study was to evaluate the effects of long-term supplementation with different oilseeds rich in 18:1 cis-9 or 18:3n-3 fatty acids on dairy cow performance over 2 consecutive lactations. This trial involved 58 Holstein cows during the first year and 35 during the second year. During the first 5 wk of the first year, all of the cows were fed the same diet; after a 4-wk transition period, the cows received 1 of 5 treatments for 2 consecutive lactations, including the dry period. Their basal diet was supplemented or not with extruded linseeds or with different forms of rapeseeds: extruded seeds, cold-pressed fat-rich meal, or whole unprocessed seeds. Oilseed amount was calculated to provide 2.5 to $3.0 \%$ additional oil in ration dry matter. Cows were fed a grass-based diet ( $75 \%$ grass silage and $25 \%$ hay) during indoor periods and grazed during outdoor periods. For the first year of experimentation, oilseed supplementation had no effect on milk, fat, protein, and lactose yields, body weight, or body condition score compared with the control treatment (no oilseed supplementation). During the indoor period, extruded linseed tended to decrease dry matter intake $(-1.5$ $\mathrm{kg} / \mathrm{d}$ ), whereas all of the oilseed treatments decreased milk protein content without changing protein yield. Cold-pressed fat-rich rapeseed meal decreased milk protein content independently of the period $(-0.29$ and $-0.19 \mathrm{~g} / 100 \mathrm{~g}$ for indoor and outdoor periods, respectively), and whole unprocessed rapeseed increased milk fat content during the outdoor period $(+0.53 \mathrm{~g} / 100$ $\mathrm{g}$ compared with the control treatment). During the second year of experimentation, the effects of oilseed supplementation during the outdoor period were similar to those observed during the first outdoor period, but the effects of oilseed supplementation differed between the 2 indoor periods. This was likely due to changes in forage quality and composition and percentage in the ration of the concentrate mixtures. Thus, the effects
\end{abstract}

Received May 26, 2011.

Accepted November 15, 2011.

${ }^{1}$ Corresponding author: yves.chilliard@clermont.inra.fr of oilseed supplementation depended on oilseed nature (rapeseed or linseed) and form (extruded seeds, coldpressed fat-rich meal, or whole unprocessed seeds) in interaction with the type of basal diet (grass silage and hay or pasture) and the concentrate composition and percentage in the ration. Effects were stable during the first indoor period, repeatable between the 2 outdoor periods, and were similar to effects observed previously in short-term studies (1 to $3 \mathrm{mo}$ ).

Key words: dairy cow performance, rapeseed processing, extruded linseed, long-term effect

\section{INTRODUCTION}

Addition of oilseed supplements to the diet of lactating dairy cows is a strategy that has been proposed for several decades to improve performance of dairy cow and milk FA profile (Chilliard and Ferlay, 2004). Lipid supplementation has been an effective approach to increase the energy density and energy efficiency of the diet, especially in grass-based diets, for which energy intake could limit milk production (Schroeder et al., 2004). Moreover, many studies have reported that oilseed supplementation can improve the nutritional quality of milk because of a decrease in milk 14:0 and 16:0 FA concentrations and an increase in FA of specific nutritional interest, such as 18:1 cis-9, 18:3n-3, and conjugated linoleic acid (cis-9,trans-11 conjugated linoleic acid). However, oilseed supplementation can also increase milk concentration of trans FA (Glasser et al., 2008), which may have adverse effects on human health (Shingfield et al., 2008; Brouwer et al., 2010). Among the different oilseeds, linseed supplementation increases milk 18:3n-3 concentration, but the availability of this source in global markets is limited compared with rapeseed (2.2 vs. 58.3 Mt in 2008; Prolea, 2009). Rapeseed production has been increasing in Europe because of the growing demand for agro-diesel fuels (Prolea, 2009). Thus, rapeseed by-products may be incorporated in large amounts into dairy rations. Rapeseed supplementation is also of interest because it induces a lower increase in milk trans-18:1 concentration than other oilseed supplements rich in PUFA (Glasser 
et al., 2008). Although the supplementation of dairy rations with ground rapeseed has been studied previously (Chilliard and Ferlay, 2004), limited research exists on the effects of supplementation with extruded rapeseed (Bayourthe et al., 2000; Neves et al., 2009) and coldpressed fat-rich rapeseed meal.

The effects of oilseed supplementation on DMI, milk yield, and composition have been widely studied during short-term periods ( 1 to $3 \mathrm{mo}$ ) and have varied according to oilseed nature and form and interactions with the type of the basal diet (Chilliard and Ferlay, 2004; Glasser et al., 2008). Addition of whole or ground linseed or rapeseed to grass-based diets (hay, silage, or pasture) has been reported to have had no effect on milk yield and to occasionally have decreased DMI, milk fat, or protein content (Schroeder et al., 2004; Petit, 2010). Additionally, 5-wk supplementation of extruded linseed was found to have increased the plasma 18:3n-3 concentration and the lipid peroxidation index, which could raise the question of putative deleterious effects of longterm supplementation on the health of cows (Gobert et al., 2009). Although few long-term studies on oilseed supplementation have been published to date, no effect was observed on milk yield, BW, or BCS when grassbased diets were supplemented with 1.6 to $3.1 \%$ oil (of the diet DM) from ground rapeseeds for $36 \mathrm{wk}$ (Moss, 2002) or for 3 consecutive lactations (Emanuelson et al., 1993; Ahlin et al., 1994). Identical results have been observed during the first 28 wk of lactation for diets based on corn silage and haylage supplemented with whole or ground linseed $(2.5 \%$ additional oil in the diet DM; Petit and Côrtes, 2010). Nonetheless, feeding ground forms of linseed or rapeseed has been found to decrease DMI (Moss, 2002; Petit and Côrtes, 2010), and the latter has decreased milk fat content of cows fed grass-based diets (Moss, 2002).

The objective of this study was to quantify the effects of oilseed nature (extruded linseed or extruded rapeseed) and form of rapeseed-derived products (extruded seeds, cold-pressed fat-rich meal, or whole unprocessed seeds) in grass-based diets during 2 consecutive lactations on milk yield and composition, BW, BCS, and plasma indicators of cow metabolic status.

\section{MATERIALS AND METHODS}

\section{Animals and Diets}

The experiment was performed at the Orcival experimental farm of the Institut National de la Recherche Agronomique (INRA), which is located in a mountain grassland area $(1,000 \mathrm{~m}$ altitude) of the Auvergne region (Puy de Dome, France). All of the procedures were conducted in accordance with the French guidelines for experimental animal use (Veissier, 1999). The experiment was conducted over 2 consecutive lactations, and each included an indoor period (winter, grass silage and hay-based diet, first half of lactation) and an outdoor period (summer, grazing pasture-based diet, second half of lactation).

First Year of Experimentation. Sixty Holstein cows (25 primiparous and 35 multiparous, calving dates between October 13, 2007, and January 14, 2008, and a BW of $681 \pm 81 \mathrm{~kg}$ during the first week postcalving) were used. During the indoor period (from calving until pasture turnout on May 5, 2008, $169 \pm 23$ DIM), mixed forage was composed of Dactylis glomerata, $75 \%$ grass silage, and $25 \%$ hay (DM basis), and it was offered to allow ad libitum intake. During outdoor period, the cows were gradually transitioned to pasture over $1 \mathrm{wk}$, starting on May 5, 2008, and then allowed to graze $20 \mathrm{~h} / \mathrm{d}$ until October 27, 2008. A simplified rotational grazing technique was used, as described by Hoden et al. (1991). Cows were moved to a different paddock when the herd daily milk yield decreased $10 \%$ relative to the maximal production registered after the entry into that paddock, and parcel rotation was adjusted to maintain forage nutritional value and an herbage height of at least $5 \mathrm{~cm}$. The grazing area consisted of temporary pastures (Dactylis glomerata and Lolium perenne) and permanent mountain pastures (less than $25 \%$ of the grazing area).

From calving until the end of wk 5 of lactation, all cows received a diet without oilseed supplementation. During this period, the concentrate mixture $(75 \%$ pelleted wheat and $25 \%$ solvent-extracted rapeseed meal, DM basis) was distributed to all of the cows at a rate of $2.5,4.0,5.2,6.5$, and $6.5 \mathrm{~kg}$ of $\mathrm{DM} / \mathrm{d}$ in wk $1,2,3$, 4 , and 5 of lactation, respectively. At the end of this period, 5 groups of 12 cows were formed based on their calving date, parity, and milk yield and fat and protein contents. Cows in each group consisted of 5 primiparous cows, 3 cows in second lactation, and 4 cows in third or greater lactation. Experimental concentrates were gradually introduced over a period of $4 \mathrm{wk}$, starting in wk 6 of lactation. Control concentrate (CTL) was composed of pelleted wheat and solvent-extracted rapeseed meal, which was partially substituted in the oilseed supplemented diets by extruded linseed [EL, extruded blend of $70 \%$ linseed and $30 \%$ wheat (weight basis); INZO $^{\circ}$, Argentan, France], extruded rapeseed [ER, extruded blend of $59 \%$ rapeseed, $29 \%$ wheat, and $12 \%$ wheat bran (weight basis); $\mathrm{INZO}^{\circ}$, cold-pressed fat-rapeseed meal (FRM, by-product of rapeseed oil extraction by cold pressure; Dock Moulin S.A., Marneffe, Belgium), or unprocessed, full fat, uncrushed, whole rapeseed $\left(\mathbf{W R} ; \mathrm{INZO}^{\circ}\right)$. The composition of the concentrate mixtures used during the indoor experimental 
Table 1. Composition of the concentrate mixtures ${ }^{1}$ used during each indoor and outdoor period

\begin{tabular}{|c|c|c|c|}
\hline \multirow[b]{2}{*}{ Item } & \multicolumn{3}{|c|}{$\%$ of concentrate DM } \\
\hline & $\begin{array}{l}\text { Pelleted } \\
\text { wheat }^{2}\end{array}$ & $\begin{array}{c}\text { Rapeseed } \\
\text { meal }^{3}\end{array}$ & $\begin{array}{c}\text { Oilseed } \\
\text { supplement }\end{array}$ \\
\hline \multicolumn{4}{|c|}{ Year 2007-2008 } \\
\hline \multicolumn{4}{|c|}{ Indoor period } \\
\hline CTL & 75 & 25 & 0 \\
\hline EL & 10 & 55 & 35 \\
\hline ER & 10 & 55 & 35 \\
\hline FRM & 26 & 0 & 74 \\
\hline WR & 11 & 67 & 22 \\
\hline \multicolumn{4}{|c|}{ Outdoor period } \\
\hline CTL & 73 & 27 & 0 \\
\hline EL & 9 & 53 & 38 \\
\hline ER & 9 & 53 & 38 \\
\hline FRM & 27 & 0 & 73 \\
\hline WR & 11 & 67 & 22 \\
\hline \multicolumn{4}{|c|}{ Year 2008-2009 } \\
\hline \multicolumn{4}{|c|}{ Indoor period } \\
\hline CTL & 90 & 10 & 0 \\
\hline EL & 71 & 0 & 29 \\
\hline ER & 48 & 20 & 32 \\
\hline FRM & 44 & 0 & 56 \\
\hline WR & 55 & 20 & 25 \\
\hline \multicolumn{4}{|c|}{ Outdoor period } \\
\hline CTL & 73 & 27 & 0 \\
\hline EL & 9 & 51 & 40 \\
\hline ER & 9 & 51 & 40 \\
\hline FRM & 40 & 0 & 60 \\
\hline WR & 9 & 60 & 31 \\
\hline
\end{tabular}

${ }^{1}$ Cows received grass silage and hay-based diets with $30 \%$ or $40 \%$ of concentrate during the first and second indoor periods, respectively, and grazed pasture supplemented with $4.5 \mathrm{~kg}$ of DM/d of concentrate during the outdoor periods. Concentrate mixtures contained no oilseed (CTL), extruded linseed (EL), extruded rapeseed (ER), cold-pressed fat-rich rapeseed meal (FRM), or whole unprocessed rapeseed (WR).

${ }^{2} 95 \%$ wheat $+5 \%$ molasses.

${ }^{3}$ Solvent-extracted rapeseed meal.

${ }^{4} \mathrm{EL}=$ extruded blend of linseed $(70 \%)$ and wheat (30\%) (weight basis); $\mathrm{ER}=$ extruded blend of rapeseed $(59 \%)$, wheat $(29 \%)$, and wheat bran $(12 \%)$ (weight basis); FRM = cold-pressed fat-rich rapeseed meal, a by-product of rapeseed oil extraction by cold pressure; $\mathrm{WR}=$ whole unprocessed rapeseed.

period (from wk 10 of lactation until pasture turnout) and the outdoor period is described in Table 1. From wk 6 of lactation until the end of the indoor period, the amount of concentrate daily offered was adjusted weekly to maintain a 70:30 forage to concentrate ratio $(\mathbf{F}: \mathbf{C})$, and each cow received $4.5 \mathrm{~kg}(\mathrm{DM})$ of concentrate during the outdoor period.

Based on their estrous behavior, cows were artificially inseminated after January 1, 2008. Pregnancy was confirmed by echography at regular intervals. During the first year of experimentation, 2 cows receiving FRM (both in their fourth lactation) were removed from the experiment at the beginning of the outdoor period due to recurrent clinical mastitis problems. The data from these 2 cows were not included in statistical analysis. After October 27, 2008, all of the cows were managed indoors. However, 4 cows that calved between October 10 and October 27, 2008, were housed earlier so that they had been housed for at least 1 wk before calving.

Second Year of Experimentation. Forty cows calved during the second year of experiment and 5 were then culled: 1 from FRM (in her first lactation during yr 1) that calved late (February 24, 2009), 1 from ER (in her fourth lactation during yr 1) due to clinical hypocalcemia, 1 from ER (in her fourth lactation during yr 1), which aborted and died during the beginning of the second outdoor period, 1 from CTL (in her seventh lactation during yr 1), and 1 for FRM (in her fourth lactation during yr 1) due to severe digestive problems postpartum. Data obtained from these cows were removed from the statistical analysis for the second year. Therefore, only 35 cows were used during the second year of experimentation ( 8 for EL, FRM, and WR, 7 for CTL, and 4 for ER). These cows were dried off at $335 \pm 29$ DIM and calved indoors between October 10, 2008, and February 13, 2009.

Cows were housed from October 27, 2008, until May 4, 2009 (pasture turnout, $142 \pm 35$ DIM), and the forages offered to allow ad libitum intake were composed of $80 \%$ silage and $20 \%$ hay (DM basis; Dactylis glomerata). After a 1-wk transition period, cows grazed from May 4 to November 3, 2009.

During the dry period, cows received $4.5 \mathrm{~kg}$ (DM) of concentrate of the same composition as that offered during the first outdoor period. After calving, the amount of concentrate offered was increased during the first $5 \mathrm{wk}(4.4,4.4,5.8,7.0$, and $8.3 \mathrm{~kg}$ of $\mathrm{DM} / \mathrm{d}$ during wk $1,2,3,4$, and 5 of lactation, respectively). From wk 6 of lactation until the end of the second indoor period, the amount of concentrate offered was adjusted weekly to maintain a 60:40 F:C ratio. During outdoor period, each cow received $4.5 \mathrm{~kg}$ (DM) of concentrate. During the second indoor period, the level of concentrate was increased from $30 \%$ (first indoor period) to $40 \%$ of the diet DM because the forages were of lower nutritional value. The composition of the concentrate mixtures used during the second indoor (from calving until pasture turnout) and outdoor periods is described in Table 1.

During the 2 indoor periods, the diets were formulated to meet at least $95 \%$ of the energy and $100 \%$ of the protein requirements to produce $30 \mathrm{~kg} / \mathrm{d}$ of milk (INRA, 2007a). The amounts of oilseed supplements were calculated to provide 3.0 and $2.5 \%$ of oil in the diet DM during indoor and outdoor periods, respectively. During outdoor periods, pasture intake was estimated from BW, milk yield, and grazing management using the software INRAtion 4.0 (INRA, 2007b, based on the predictive model described in INRA, 2007a). During indoor periods, forages were mixed daily and offered at 
$1000 \mathrm{~h}$ to allow $10 \%$ refusals. Concentrates were prepared daily and offered at equal amounts at 1000 and $1730 \mathrm{~h}$ during indoor periods and at 0700 and $1530 \mathrm{~h}$ during outdoor periods. Cows were allowed free access to water and received $200 \mathrm{~g} / \mathrm{d}$ of a mineral and vitamin premix containing $60 \mathrm{~g} / \mathrm{kg}$ of $\mathrm{P}, 180 \mathrm{~g} / \mathrm{kg}$ of $\mathrm{Ca}, 50 \mathrm{~g} /$ $\mathrm{kg}$ of $\mathrm{Mg}, 50 \mathrm{~g} / \mathrm{kg}$ of $\mathrm{Na}, 15 \mathrm{~g} / \mathrm{kg}$ of S, 600,000 IU $/ \mathrm{kg}$ of vitamin A, 120,000 IU $/ \mathrm{kg}$ of vitamin D3, 1,300 IU/ $\mathrm{kg}$ of vitamin $\mathrm{E}, 1,300 \mathrm{mg} / \mathrm{kg}$ of $\mathrm{Cu}, 6,000 \mathrm{mg} / \mathrm{kg}$ of $\mathrm{Zn}, 3,500 \mathrm{mg} / \mathrm{kg}$ of $\mathrm{Mn}, 62 \mathrm{mg} / \mathrm{kg}$ of I, $32 \mathrm{mg} / \mathrm{kg}$ of $\mathrm{Co}$, and $20 \mathrm{mg} / \mathrm{kg}$ of Se. Cows were milked at 0630 and $1600 \mathrm{~h}$ in a milking parlor and were housed in a freestall barn during indoor periods. Mastitis, metritis, hypocalcemia, and other disorders were recorded.

\section{Sampling, Measurements, and Analyses}

During the 2 indoor periods, forages and concentrates were offered individually to the cows in individual troughs fitted with electronically controlled gates, and forage refusals were weighed $4 \mathrm{~d}$ a week. At the same time, subsamples of feed and refusals were collected each week and pooled monthly to determine the DM content after $48 \mathrm{~h}$ at $80^{\circ} \mathrm{C}$ (INRA, 1981). For chemical analyses, samples of forages and concentrates were collected twice during the first indoor (February 27 and April 7, 2008) and outdoor periods (June 6 and September 3, 2008 ) and 3 times during the second indoor (February 2, March 9, and April 20, 2009) and outdoor periods (June 2, June 29, and September 1, 2009), yielding 10 samples per feedstuff. Pasture samples were obtained from subsamples (cut with a scythe at a height of $5 \mathrm{~cm}$ ) collected from 4 patches in the paddock where cows grazed on the day of the sampling. The 4 subsamples were then pooled per sampling day and paddock. Feedstuff samples were stored at $-20^{\circ} \mathrm{C}$ before lyophilization (Thermovac TM-20, Froilabo, Ozoir-La-Ferrière, France). Samples were sieved through a $0.6-\mathrm{mm}$ screen and analyzed according to standard methods (AOAC, 1997) for ash (method 942-05), CP (method 984-13), starch (only for pelleted wheat, EL, and ER; polarimetric method 14031-032), and ether extract (after acid hydrolysis; method 920-39). For NDF and ADF, a sequential procedure with prior amylolytic, proteolytic, and fat-removing treatments was used (Van Soest et al., 1991; adapted for Ankom ${ }^{2000}$ Fiber Analyzer, Ankom Technology, Fairport, NY). The contents of energy and true protein truly digestible in the small intestine (PDI) were calculated for all of the feeds using their ash, CP, ADF, and ether extract contents (PrevAlim 3.23; INRA, 2006). Chemical composition and energy and PDI values of the feedstuffs are presented in Table 2 .
During the entire experiment, BW and BCS were recorded during the first week of lactation, and $\mathrm{BW}$ was measured every 2 wk and BCS every 4 wk thereafter. Daily milk yield was recorded individually and subsamples $(30 \mathrm{~mL})$ were collected at 4 consecutive milkings each week, preserved in tubes with bronopolB2 (Trillaud, Surgères, France), and stored at $4^{\circ} \mathrm{C}$. The individual samples from each milking were subsequently analyzed for fat, protein, and lactose contents, and SCC (Galilait, Theix, France) using mid-infrared spectrometry (AOAC, 1997; Milkoscan 4000; Foss Electric, Hillerød, Denmark). Additionally, during the first year of experimentation, 1 subsample $(60 \mathrm{~mL})$ was collected in tubes without additive during morning milking, stored at $4^{\circ} \mathrm{C}$, and analyzed within $24 \mathrm{~h}$ for milk urea content. Milk urea was measured at the end of the pre-experimental period (wk 5 of lactation), twice during the indoor period $(72 \pm 17.0$ and $141 \pm 23.1$ DIM) and once at the end of the outdoor period (288 \pm 23.1 DIM). Milk urea content was determined (Galilait) by the dimethylamino-4-benzaldehyde colorimetric method (Potts, 1967).

Blood samples were collected from the coccygeal vein or artery using tubes containing EDTA $(2.1 \mathrm{mg} / \mathrm{mL})$. Blood sampling was performed after morning milking and before feeding on the same dates as for milk urea analyses plus one date at the beginning of the outdoor period (197 \pm 23.1 DIM). Blood samples were kept on ice after sampling and plasma was separated within 1 $\mathrm{h}$, by centrifugation at $1,400 \times g$ for $15 \mathrm{~min}$ at $4^{\circ} \mathrm{C}$, and frozen at $-20^{\circ} \mathrm{C}$ until it was analyzed for NEFA, BHBA, acetate, glucose, and insulin concentrations. Plasma NEFA, glucose, and acetate concentrations were determined by spectrophotometry using glucose dehydrogenase (Glucose RTU kit; BioMérieux, Lyon, France), acyl-CoA synthetase (Wako NEFA HR2 kit; Oxoid, Dardilly, France), and L-malate dehydrogenasecitrate synthase-acyl-CoA synthetase methods (Enzyplus EZA 811 + kit, Biocontrol Systems, Lyon, France), respectively. The BHBA concentration was determined as described by Brashear and Cook (1983). Insulin concentration was determined using the Insulin CT kit (CIS Bio International, Gif-sur-Yvette, France). Intraand interassay CV were 8.0 and $8.6 \%$ for NEFA, 3.4 and $4.8 \%$ for BHBA, 7.8 and $8.8 \%$ for acetate, 1.1 and $2.0 \%$ for glucose, and 7.9 and $6.6 \%$ for insulin, respectively.

\section{Calculations and Statistical Analyses}

First Year of Experimentation. Statistical analysis was performed using the Mixed procedure of SAS (SAS Institute, 2003). A covariate term centered by lactation number (first, second, and third or greater) 
Table 2. Chemical composition, energy, and protein contents of feedstuffs

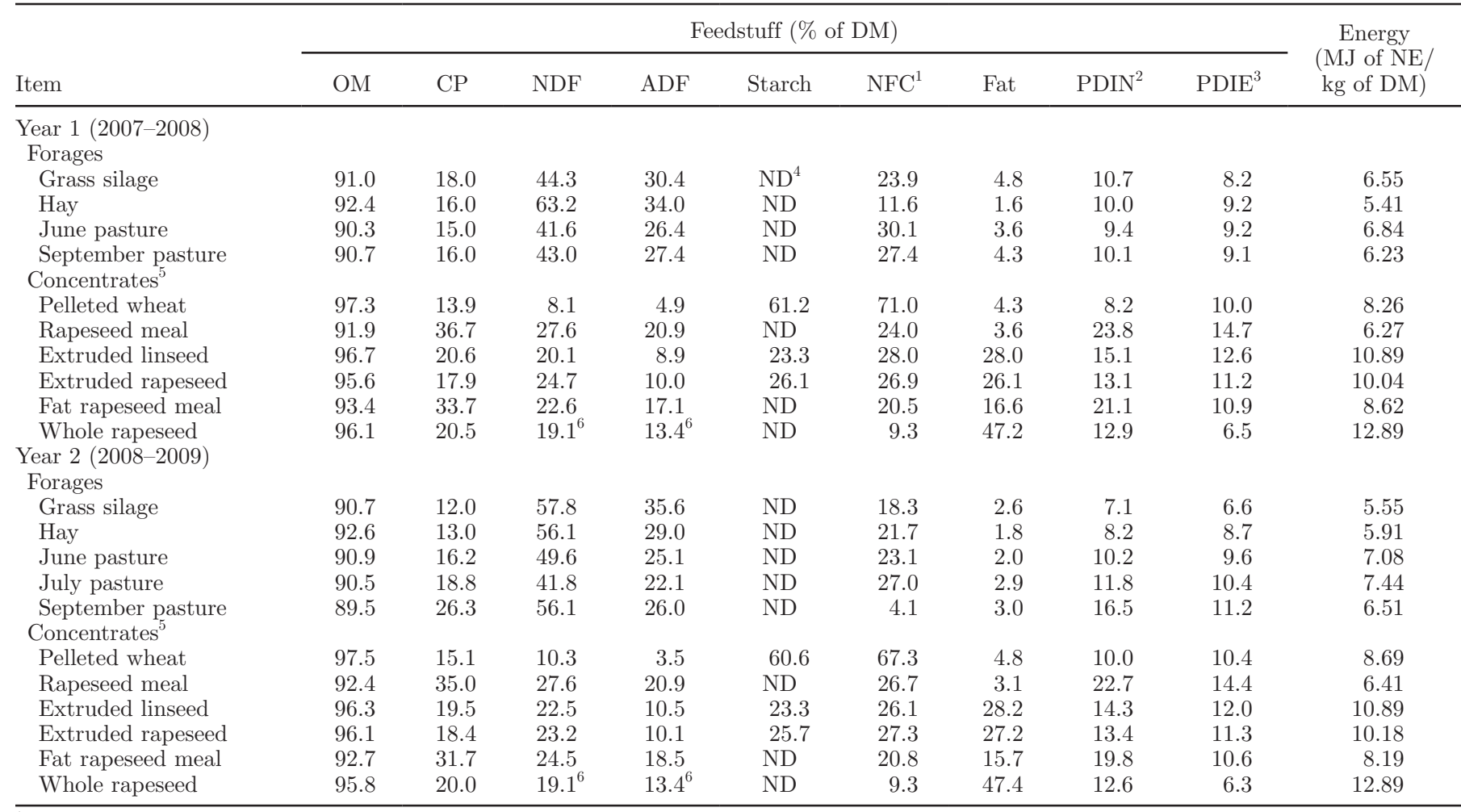

${ }^{1} \mathrm{NFC}=\mathrm{OM}-\mathrm{CP}-\mathrm{NDF}-$ fat

${ }^{2}$ True protein truly digestible in the small intestine when protein supply is limited (INRA, 2007a).

${ }^{3}$ True protein truly digestible in the small intestine when energy supply is limited (INRA, 2007a).

${ }^{4} \mathrm{ND}=$ not determined.

${ }^{5}$ Pelleted wheat $=95 \%$ wheat $+5 \%$ molasses; rapeseed meal $=$ solvent-extracted rapeseed meal; extruded linseed $=$ extruded blend of linseed $(70 \%)$ and wheat $(30 \%)$ (weight basis); extruded rapeseed = extruded blend of rapeseed (59\%), wheat (29\%), and wheat bran (12\%) (weight basis); fat rapeseed meal = cold-pressed fat-rich rapeseed meal, a by-product of rapeseed oil extraction by cold pressure; whole rapeseed $=$ whole unprocessed rapeseed.

${ }^{6}$ Estimations from INRA (2007a).

was calculated using the data obtained from wk 2 and 3 of lactation for BW, at calving for BCS, from wk 3,4 , and 5 of lactation for DMI, milk yield, and milk composition, and from wk 5 of lactation for milk urea content and plasma metabolite and insulin concentrations.

Indoor and outdoor data were analyzed separately for all variables. During the indoor period, data were expressed according to week of lactation (wk 10 to 20). During the outdoor period, data were expressed according to calendar week relative to pasture turnout (i.e., from 19 to 36 calendar weeks, until $294 \pm 23$ DIM). The model for repeated-measures analyses included covariate, treatment, week (lactation or calendar), lactation number, treatment by week, and lactation number by week interactions as fixed effects, and cow as a random effect. A second covariate term was included for the outdoor period. It was calculated as the deviation between individual DIM and average DIM for all of the cows at the date of pasture turnout. If one interaction was not significant, it was removed from the model. Additionally, week and its interactions were removed from the model to study nonrepeated data (BW change and BCS change: wk 20 minus wk 10 of lactation and calendar wk 36 minus calendar wk 20 for indoor and outdoor periods, respectively).

To test the interactions between treatments and periods, individual means of milk yield and composition, $\mathrm{BW}$, and BCS were calculated from wk 10 to 16 of lactation, when all of the cows were managed indoors and from wk 30 to 36 of lactation, when all of the cows were managed outdoors. The statistical model included covariate, treatment, lactation number, period, and treatment by period and lactation number by period interactions as fixed effects, cow as a random effect, and period as a repeated measure.

Second Year of Experimentation. Intake and diet nutrient composition data were analyzed as the means of the data from wk 10 to 16 of lactation. The 
statistical model included the covariate, treatment, and parity for the first year of experimentation as fixed effects, and cow as a random effect.

For total DMI, milk yield and composition, BW, BCS, BW and BCS changes, and energy and PDI balances, heterogeneity of performance potential was observed among the 5 treatment groups due to the exclusion of some cows. Therefore, to control the animal factors, we chose to study changes in the long-term treatment effects using the differences of individual performances between the first and second year of experimentation. This comparison was made at the same physiological stage within each indoor and outdoor period. For each variable, within-cow differences between yr 1 and 2 (yr 2 minus yr 1) were calculated from the mean of the individual data recorded from wk 10 to 16 of lactation (corresponding to indoor periods), and from wk 30 to 36 of lactation (corresponding to outdoor periods). For each period (indoor or outdoor), the statistical model included treatment and parity for the first year of experimentation as fixed effects, and cow as a random effect.

Logarithmic transformation was used when needed to comply with the assumptions of normality and homoscedasticity of residuals. When transformation was needed (milk SSC, plasma NEFA, BHBA, acetate and insulin concentrations), least squares means and standard errors of the mean were estimated from untransformed values, whereas $P$-values reflect statistical analysis of transformed data. Significance was declared at $P \leq 0.05$, and trends were considered at $0.05<P$ $\leq 0.10$. Values reported are least squares means and SEM.

\section{RESULTS}

\section{First Year of Experimentation}

During the indoor period, we obtained the target oil level in the diet DM for all oilseed treatments except FRM (3.8\% instead of $3 \%$ additional oil in the diet DM; Table 3) because the fat content of FRM was underestimated at the beginning of the experiment. Compared with that in CTL, forage intake decreased for EL and FRM (Table $3 ; P=0.05$ ) and was unchanged for ER and WR. Consequently, total DMI tended to be lower for EL than for CTL and WR $(P=0.08)$, but calculated energy intake was not affected by treatment $(P$ $=0.21)$. Intake of PDI was lower for FRM than for ER and WR $(P=0.03)$. The diet starch and NFC contents were higher in CTL than in oilseed treatments $(+9.7$ and $+9.0 \%$ DM, respectively; $P<0.001)$. The diet NDF and ADF contents were higher for ER and WR than for CTL and FRM $(P<0.001)$.

During the first $44 \mathrm{wk}$ of lactation, the total average production across the 5 treatment groups was $7,555 \mathrm{~kg}$ of milk per cow, containing $3.70,3.04$, and $4.84 \%$ of fat, protein, and lactose, respectively. Milk yield and milk fat and protein contents are presented in Figure 1. Pe-

Table 3. Intake and nutrient composition of diets containing different oilseed supplements during the indoor period (wk 10 to 20 of lactation) of the first year of experimentation

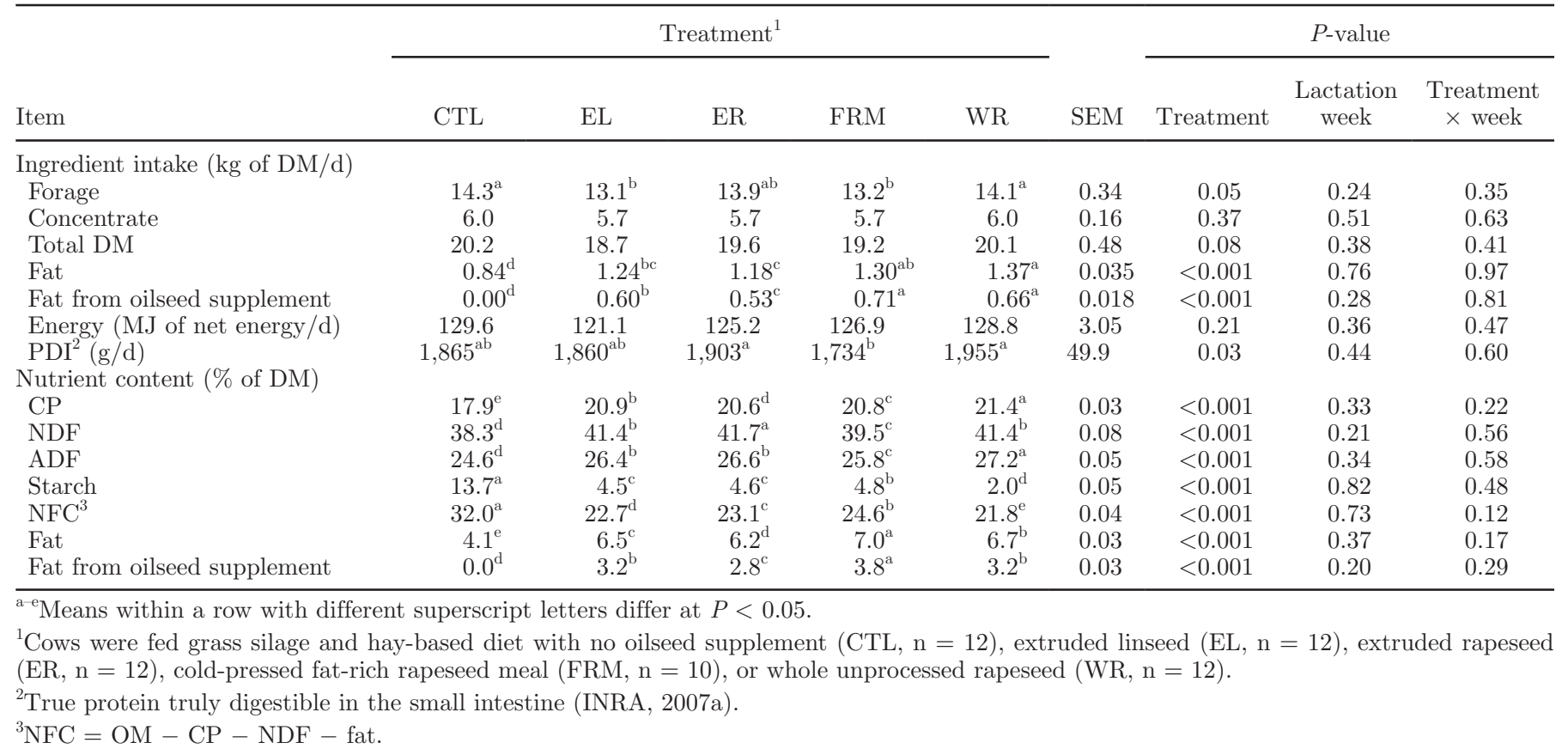


riod (indoor vs. outdoor) had effects on milk yield and composition $(P<0.001$; data not shown), which were more variable during the outdoor period than during the indoor period (Table 4, Figure 1).

During the first year (indoor and outdoor periods), milk yield was generally not affected by treatment (Table 4; $P>0.20$ ), except during calendar wk 28, 32, and 33 of the outdoor period (Figure 1), when milk yield tended to be lower for WR than for EL, ER, and FRM $(-2.8 \mathrm{~kg} / \mathrm{d} ; P<0.10)$. Milk fat content was not affected by treatment during the indoor period (Table 4; $P=0.60)$, whereas it was greater for WR starting 2 wk after pasture turnout (Figure $1 \mathrm{~B}, P<0.01$ ); milk fat yield was not modified by treatment $(P>0.20)$.

All of the oilseed treatments resulted in decreased milk protein content during the indoor period (Table 4; $P<0.001)$. This effect was greater during the indoor period and persisted during the outdoor period for FRM (compared with CTL: -0.29 and $-0.19 \mathrm{~g} / 100 \mathrm{~g}$ during indoor and outdoor periods, respectively). However, FRM did not affect milk protein content at the end of the outdoor period (calendar wk 33-36, Figure $1 \mathrm{C} ; P>0.20)$.

Treatment had no effect on milk lactose content (Table 4; $P>0.15$ ) except during the last $3 \mathrm{wk}$ of the outdoor period (calendar wk 34-36) when FRM increased milk lactose content compared with that of CTL, ER, and WR $(P<0.05)$. In general, milk protein and lactose yields were not modified by the treatments (Table 4; $P>0.15$ ), except for 3 wk during the outdoor period (calendar wk 28, 32, and 33) when the milk protein and lactose yields were lower for WR than for EL, ER, and FRM ( -87 and $-143 \mathrm{~g} / \mathrm{d}$ on average, respectively; $P<0.10)$.

Overall, milk urea content was higher during the outdoor than the indoor period $(+0.04 \mathrm{~g} / \mathrm{L} ; P<0.001)$. During the indoor period, milk urea content was lower for CTL than for oilseed treatments and was higher for WR than for EL (Table 4; $P<0.001$ ). During the outdoor period, milk urea content was the highest for ER and WR $(P<0.01)$.

In general, treatment did not affect BW, BCS, BW change, or BCS change (Table $4 ; P>0.15$ ). Calculated energy balance tended to be greater for WR than for EL and ER (Table 4; $P=0.07$ ), and the calculated PDI balance was lower for CTL and FRM than for EL, $\mathrm{ER}$, and WR $(P<0.001)$; the calculated energy and PDI balances were always positive during the period studied. After culling the 2 cows from FRM for health problems during the first year of experimentation, milk SCC (Table 4); the number of cases of mastitis, metritis, ketosis, or lameness; and the number of cows with at least one mastitis or lameness did not differ between treatments $(P>0.50$; data not shown $)$.
During the indoor period, plasma BHBA concentration was higher for FRM than for CTL, ER, and WR (Table $4 ; P=0.03$ ). During the outdoor period, plasma NEFA concentration was higher for FRM than for CTL, EL, and WR $(P=0.04)$, and plasma insulin concentration tended to be lower for WR compared with other treatments $(P=0.07)$. Treatments did not affect plasma glucose or acetate concentrations $(P>0.10)$.

\section{Second Year of Experimentation}

During the indoor period, the oil content in the diet was greater than the target level for all of the oilseed treatments $(3.4,3.5,3.5$, and $5.0 \%$ additional oil in the diet DM for EL, ER, FRM, and WR, respectively, Table 5). This was due to an underestimation of the fat content of oilseeds (especially for WR), which was linked to unexpected variations between the preliminary chemical analyses at the beginning of the trial and the final analyses for all of the batches of each feedstuff. Forage and concentrate intakes, and NDF, $\mathrm{ADF}$, starch, NFC, and fat contents in the diets varied according to the treatment (Table 5; $P<0.001$ ).

During the first $44 \mathrm{wk}$ of lactation, the total average production across the 5 treatment groups was 8,146 $\mathrm{kg}$ of milk per cow, containing 3.64, 3.00, and $4.83 \%$ fat, protein, and lactose, respectively. Performance during the second year of experimentation was studied as the individual difference relative to the first year (see the Materials and Methods section). Within-cow differences between the first and the second outdoor periods did not change according to the treatment for milk yield and composition or BW and BCS (Table 6; $P>0.08)$, except for milk protein content $(P=0.04)$, which increased in the second outdoor period for ER, or remained stable for FRM and WR compared with EL, which decreased.

In contrast, differences between the first and second indoor periods changed among treatments for all variables except milk lactose content, BCS, BW change, and BCS change (Table 6; $P>0.10$ ). Between the first and second indoor periods, total DMI increase was greater for ER, FRM, and WR than for EL $(P$ $<0.001)$. The milk yield increase was greater for ER and FRM than for CTL and WR $(P=0.02)$. Milk fat content decreased $(P<0.01)$ for EL, ER, and CTL in contrast to the slight numerical increase observed for FRM, whereas milk fat yield increased $(P=0.01)$ by $268 \mathrm{~g} / \mathrm{d}$ for FRM in contrast to the numerical increase $(<70 \mathrm{~g} / \mathrm{d})$ for other treatments. Milk protein content decreased $(P=0.04)$ between the first and second indoor periods for EL, whereas a numerical increase or no change was recorded for ER, FRM, and WR. The milk protein yield increase was greater for ER and FRM 

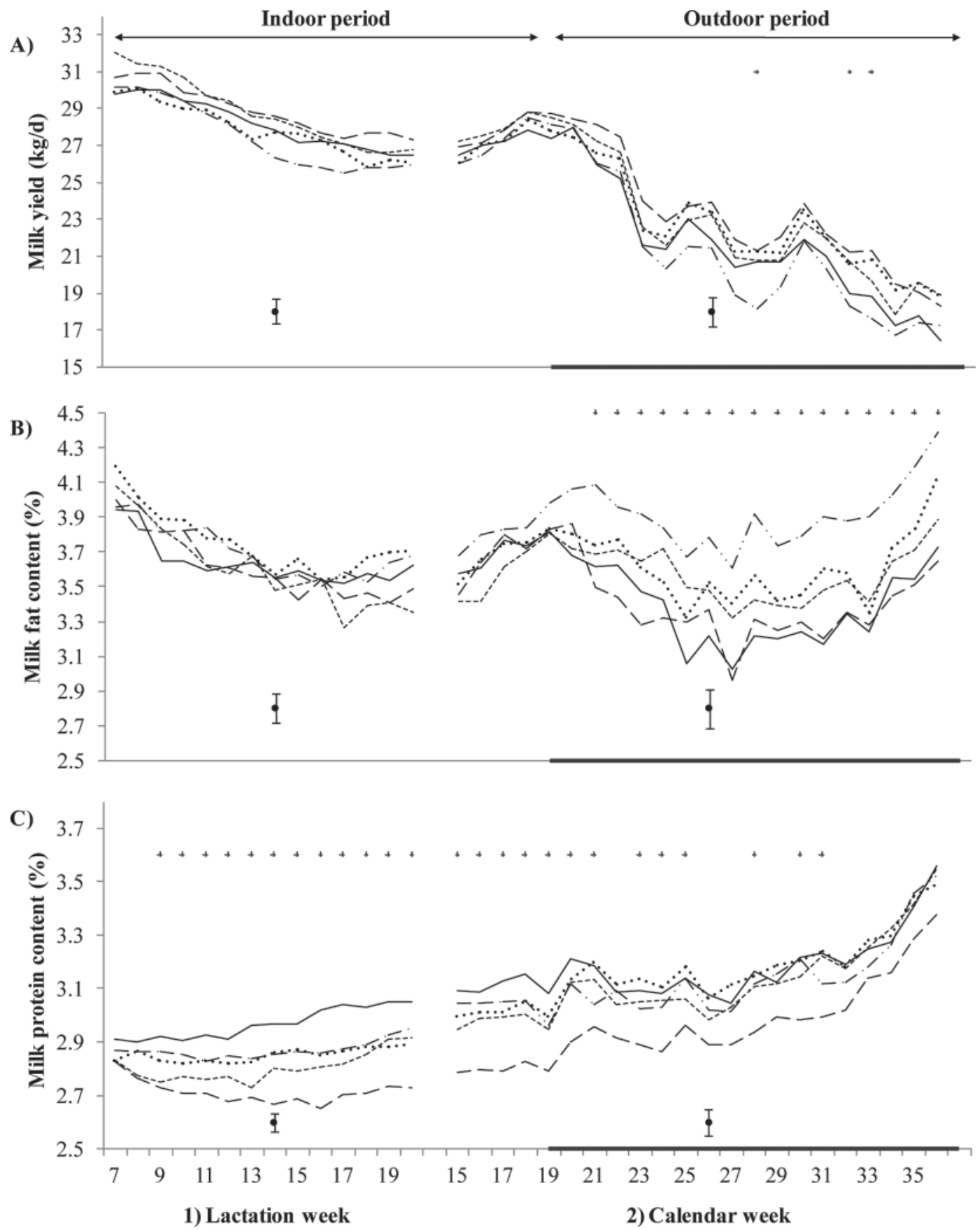

Figure 1. Milk yield (A), milk fat (B), and milk protein contents (C) during the first year of experimentation. Cows were fed no oilseed

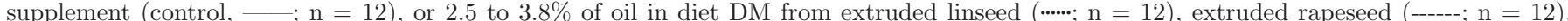
cold-pressed fat-rich rapeseed meal $(-\ldots \ldots ; \mathrm{n}=10)$, or whole unprocessed rapeseed $(-\cdots-; \mathrm{n}=12)$. Basal diets were composed of grass silage and hay during indoor period, and grazed pasture during outdoor period ( $\mathrm{x}$ axis in boldface). The curves were obtained from data averaged either by lactation weeks (series 1, left side of panels, indoor period) or by calendar weeks (series 2, right side panels, end of indoor period and outdoor period). The pooled SEM for diet effects is represented by a dot $(\bullet)$ with error bars. $P<0.001$ for week effect in all statistical models, $P<0.05$ for diet effect for panels B series 2 , C series 1 , and $\mathrm{C}$ series $2, P<0.05$ for diet $\times$ week effect for panels A series 1 , B series 2 , C series 1 , and $\mathrm{C}$ series 2 . The + symbol indicates a significant diet effect in the considered week.

$(>160 \mathrm{~g} / \mathrm{d})$ than for other treatments $(<60 \mathrm{~g} / \mathrm{d} ; P<$ 0.001). Milk lactose yield increase from first to second indoor periods was greater for ER and FRM than for CTL and WR $(P=0.01)$.
Between the first and second indoor periods, the BW increase was more important for ER and FRM than for CTL and EL $(P=0.05)$. The calculated energy balance increased more for WR than for CTL, EL, and 
Table 4. Milk yield and composition, BW, BCS, energy and protein balances, and plasma metabolite and insulin concentrations for cows fed different oilseed supplements during the indoor and outdoor periods of the first year of experimentation

\begin{tabular}{|c|c|c|c|c|c|c|c|c|c|c|c|c|c|c|c|c|c|c|}
\hline \multirow[b]{3}{*}{ Item } & \multicolumn{9}{|c|}{ Indoor period $^{1}$} & \multicolumn{9}{|c|}{ Outdoor period $^{2}$} \\
\hline & \multicolumn{5}{|c|}{ Treatment $(\text { Trt })^{3}$} & \multicolumn{4}{|c|}{$P$-value } & \multicolumn{5}{|c|}{ Treatment $^{3}$} & \multicolumn{4}{|c|}{$P$-value } \\
\hline & CTL & EL & ER & FRM & WR & SEM & Trt & $\mathrm{Wk}$ & $\begin{array}{l}\text { Trt } \times \\
\text { Wk }\end{array}$ & CTL & EL & ER & FRM & WR & SEM & Trt & Wk & $\begin{array}{l}\text { Trt } \times \\
\text { Wk }\end{array}$ \\
\hline $\begin{array}{l}\text { Milk yield }(\mathrm{kg} / \mathrm{d}) \\
\text { Milk fat }\end{array}$ & 27.8 & 27.3 & 28.1 & 28.4 & 26.8 & 0.69 & 0.48 & $<0.001$ & 0.39 & 21.6 & 22.6 & 22.4 & 23.2 & 21.0 & 0.78 & 0.24 & $=0.001$ & 0.04 \\
\hline Content (\%) & 3.58 & 3.68 & 3.51 & 3.54 & 3.64 & 0.090 & 0.60 & $<0.001$ & 0.10 & $3.40^{\mathrm{b}}$ & $3.62^{\mathrm{b}}$ & $3.58^{\mathrm{b}}$ & $3.40^{\mathrm{b}}$ & $3.93^{\mathrm{a}}$ & 0.113 & $<0.01$ & $<0.001$ & 0.02 \\
\hline Yield $(\mathrm{g} / \mathrm{d})$ & 983 & 982 & 974 & 996 & 961 & 34.2 & 0.96 & $<0.001$ & 0.20 & 725 & 805 & 802 & 783 & 809 & 35.4 & 0.33 & $<0.001$ & 0.36 \\
\hline \multicolumn{19}{|l|}{ Milk protein } \\
\hline Content (\%) & $2.99^{\mathrm{a}}$ & $2.86^{\mathrm{b}}$ & $2.81^{\mathrm{b}}$ & $2.70^{\mathrm{c}}$ & $2.87^{\mathrm{b}}$ & 0.036 & $<0.001$ & $<0.001$ & 0.04 & $3.19^{\mathrm{a}}$ & $3.20^{\mathrm{a}}$ & $3.15^{\mathrm{a}}$ & $3.00^{\mathrm{b}}$ & $3.14^{\mathrm{a}}$ & 0.050 & 0.04 & $<0.001$ & 0.04 \\
\hline Yield (g/d) & 819 & 771 & 774 & 756 & 759 & 22.7 & 0.23 & $<0.001$ & 0.05 & 678 & 716 & 695 & 685 & 647 & 22.4 & 0.21 & $<0.001$ & $<0.01$ \\
\hline \multicolumn{19}{|l|}{ Milk lactose } \\
\hline Content (\%) & 4.86 & 4.88 & 4.86 & 4.91 & 4.82 & 0.038 & 0.38 & $<0.001$ & 0.79 & 4.77 & 4.82 & 4.77 & 4.85 & 4.72 & 0.049 & 0.20 & $<0.001$ & 0.01 \\
\hline Yield $(\mathrm{g} / \mathrm{d})$ & 1,353 & 1,332 & 1,361 & 1,381 & 1,293 & 35.4 & 0.40 & $<0.001$ & 0.55 & 1,035 & 1,090 & 1,070 & 1,114 & 994 & 40.0 & 0.19 & $<0.001$ & 0.02 \\
\hline Milk SCC $(1,000 / \mathrm{mL})$ & 557 & 711 & 228 & 227 & 346 & 201 & 0.44 & 0.15 & 0.50 & 319 & 889 & 262 & 279 & 360 & 470 & 0.60 & $<0.001$ & 0.78 \\
\hline Milk urea ${ }^{4}(\mathrm{~g} / \mathrm{L})$ & $0.18^{\mathrm{c}}$ & $0.26^{\mathrm{b}}$ & $0.28^{\mathrm{ab}}$ & $\quad 0.20^{\mathrm{c}}$ & $0.31^{\mathrm{a}}$ & 0.012 & $<0.001$ & $<0.001$ & 0.03 & $0.26^{\mathrm{b}}$ & $0.27^{\mathrm{b}}$ & $0.32^{\mathrm{a}}$ & $0.24^{\mathrm{b}}$ & $0.32^{\mathrm{a}}$ & 0.019 & $<0.01$ & & \\
\hline $\mathrm{BW}^{5}(\mathrm{~kg})$ & 629 & 621 & 617 & 603 & 618 & 7.7 & 0.19 & 0.83 & 0.47 & 587 & 584 & 577 & 562 & 575 & 9.7 & 0.39 & $<0.001$ & 0.42 \\
\hline $\mathrm{BW}^{6}$ change $(\mathrm{kg})$ & 11 & 1 & 1 & -1 & -3 & 5.6 & 0.34 & & & 22 & 37 & 25 & 31 & 31 & 8.9 & 0.70 & & \\
\hline $\operatorname{BCS}(0-5)^{7}$ & 1.9 & 1.7 & 1.5 & 1.6 & 1.4 & 0.17 & 0.19 & 0.48 & 0.34 & 1.9 & 1.8 & 1.6 & 1.8 & 1.5 & 0.17 & 0.25 & 0.009 & 0.03 \\
\hline BCS change $^{6}$ & 0.0 & 0.0 & 0.0 & 0.3 & 0.1 & 0.14 & 0.43 & & & -0.1 & 0.0 & 0.2 & 0.1 & 0.2 & 0.13 & 0.17 & & \\
\hline \multicolumn{19}{|l|}{ Balance $^{8}$} \\
\hline $\begin{array}{l}\text { Energy } \\
\text { (MJ of net e }\end{array}$ & 6.5 & 4.2 & 2.7 & 5.7 & 10.7 & 2.18 & 0.07 & $<0.001$ & 0.32 & & & & & & & & & \\
\hline $\begin{array}{l}(\mathrm{MJ} \text { of net energy/d) } \\
\mathrm{PDI}^{9}(\mathrm{~g} / \mathrm{d})\end{array}$ & $156^{\mathrm{b}}$ & $267^{\mathrm{a}}$ & $274^{\mathrm{a}}$ & $149^{\mathrm{b}}$ & $335^{\mathrm{a}}$ & 29.7 & $<0.001$ & $<0.001$ & 0.67 & & & & & & & & & \\
\hline \multicolumn{19}{|c|}{ Plasma concentrations ${ }^{10}$} \\
\hline NEFA $(\mu M)$ & 197 & 206 & 221 & 173 & 173 & 22.5 & 0.33 & $<0.001$ & 0.45 & $107^{\mathrm{b}}$ & $119^{\mathrm{b}}$ & $135^{\mathrm{ab}}$ & $150^{\mathrm{a}}$ & $116^{\mathrm{b}}$ & 11.0 & 0.04 & $<0.001$ & 0.14 \\
\hline BHBA $(\mu M)$ & $512^{\mathrm{b}}$ & $602^{\mathrm{ab}}$ & $554^{\mathrm{b}}$ & $643^{\mathrm{a}}$ & $563^{\mathrm{b}}$ & 33.9 & 0.03 & $<0.01$ & 0.10 & 806 & 812 & 831 & 821 & 777 & 66.6 & 0.98 & 0.30 & $<0.001$ \\
\hline Acetate $(\mu M)$ & 561 & 533 & 568 & 598 & 548 & 29.2 & 0.57 & 0.28 & 0.57 & 650 & 635 & 561 & 532 & 559 & 43.4 & 0.16 & 0.08 & $<0.01$ \\
\hline Glucose (mg/dL) & 66 & 66 & 66 & 66 & 65 & 0.9 & 0.83 & $<0.001$ & 0.70 & 66 & 69 & 66 & 67 & 66 & 1.0 & 0.13 & 0.10 & 0.33 \\
\hline Insulin $(\mu \mathrm{IU} / \mathrm{mL})$ & 15 & 16 & 17 & 16 & 17 & 1.1 & 0.79 & $<0.001$ & 0.32 & 21 & 20 & 20 & 20 & 17 & 1.0 & 0.07 & $<0.001$ & 0.54 \\
\hline
\end{tabular}

${ }^{\mathrm{a}-\mathrm{c}}$ Means within a row with different superscript letters differ at $P<0.05$.

${ }^{1}$ Week 10 to 20 of lactation, grass silage and hay-based diet.

${ }^{2}$ Calendar wk 19 to 36 , pasture-based diet.

${ }^{3}$ Cows fed no oilseed supplement $(\mathrm{CTL}, \mathrm{n}=12)$, or 2.5 to $3.8 \%$ of oil in diet DM from extruded linseed (EL, $\left.\mathrm{n}=12\right)$, extruded rapeseed $($ ER, $\mathrm{n}=12)$, cold-pressed fat-rich rapeseed meal (FRM, $\mathrm{n}=10$ ), or whole unprocessed rapeseed (WR, $\mathrm{n}=12$ ).

${ }^{4}$ Measured at wk $10( \pm 2.4)$ and $20( \pm 3.3)$ of lactation during the indoor period and at calendar wk 36 during the outdoor period.

${ }^{5}$ Recorded every 2 wk.

${ }^{6}$ Changes of BW and BCS between wk 10 and 20 of lactation during the indoor period (wk 20 minus wk 10), and between calendar wk 20 and 36 during the outdoor period (wk 36 minus wk 20)

${ }^{7}$ Recorded every 4 wk.

${ }^{8}$ Balance $=$ intake minus requirements for maintenance and production, calculated according to INRA (2007a).

${ }^{9}$ True protein truly digestible in the small intestine (INRA, 2007a).

${ }^{10}$ Measured at wk $10( \pm 2.4)$ and $20( \pm 3.3)$ of lactation during the indoor period and at calendar wk 23 and 36 for the outdoor period. 
Table 5. Intake and nutrient composition of diets containing different oilseed supplements during the indoor period (wk 10 to 16 of lactation) of the second year of experimentation

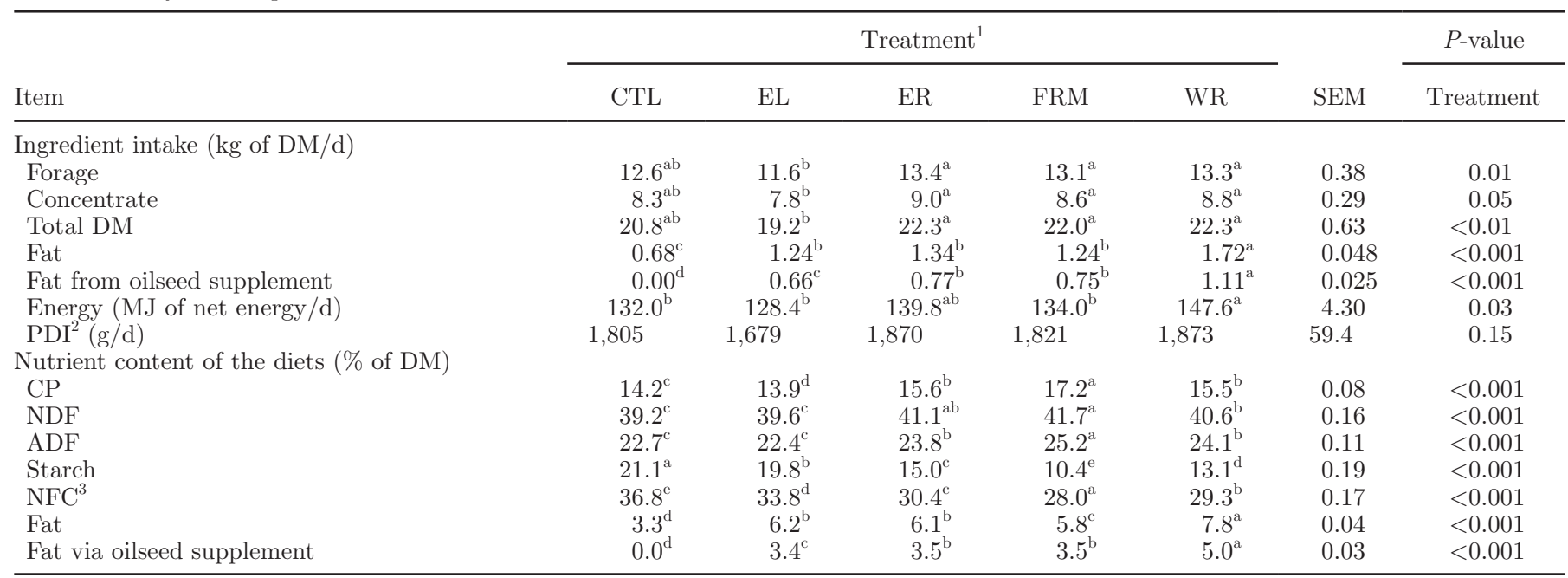

${ }^{\mathrm{a} e}$ Means within a row with different supercript letters differ at $P<0.05$.

${ }^{1}$ Cows fed grass silage and hay-based diet with no oilseed supplement $(\mathrm{CTL}, \mathrm{n}=7)$, extruded linseed $($ EL, $\mathrm{n}=8)$, extruded rapeseed $($ ER, $\mathrm{n}=$ 4), cold-pressed fat-rich rapeseed meal (FRM, $\mathrm{n}=8$ ), or whole unprocessed rapeseed (WR, $\mathrm{n}=8)$.

${ }^{2}$ True protein truly digestible in the small intestine (INRA, 2007a).

${ }^{3} \mathrm{NFC}=\mathrm{OM}-\mathrm{CP}-\mathrm{NDF}-$ fat.

FRM, in which only small changes were observed $(P$ $=0.01$ ). The calculated PDI balance decreased more for EL than for CTL, FRM, and WR $(P=0.02)$. As was observed for the first year of experimentation, the number of cases of mastitis, metritis, ketosis, lameness, and the number of cows with at least one mastitis or lameness case did not differ between treatments $(P>$ 0.50 , data not shown).

\section{DISCUSSION}

\section{First Year of Experimentation}

The responses of milk yield and composition to the different oilseed supplementations were stable after the 4 wk of transition to the experimental diets during the indoor period and after $2 \mathrm{wk}$ following the turnout to pasture during outdoor period (Figure 1). Long-term stability of these responses to oilseed feeding has been previously observed for supplementation of a grass silage-based diet with $3.1 \%$ oil in the diet DM from ground rapeseed (Moss, 2002) or of a corn silage and haylage-based diet with $2.5 \%$ oil in the diet DM from ground linseed (Petit and Côrtes, 2010). In contrast, the high short-term (daily or weekly) variability in milk yield and composition during the outdoor period could be due to pasture management because rotational grazing is known to affect milk yield and composition cyclically (Hoden et al., 1991).
Effects of Oilseed Nature (EL vs. ER). During the first year (36 wk of treatment), EL and ER did not affect milk yield or milk fat content compared with CTL (Table 4). These results are in agreement with those of a short-term study (6 wk) involving EL supplementation of a hay-based diet $(2.4 \%$ oil in the diet DM; Egger et al., 2007). Furthermore, a greater level of EL incorporation ( 4.7 to $5.8 \%$ of oil in the diet DM) for up to 4 wk has been shown to decrease milk yield, milk fat content, or both in diets based on corn silage or mixture of grass silage and corn silage (Gonthier et al., 2005; Akraim et al., 2007; Chilliard et al., 2009; Ferlay et al., 2010). However, the supplementation of a corn silage-based diet with ER (2.0\% of oil in the diet DM) has been shown to have no effect on milk yield but did decrease milk fat content (Bayourthe et al., 2000).

Compared with CTL, EL and ER decreased milk protein content during the indoor period (Table 4). Previous research has found similar decreases in milk protein content for ground linseed or rapeseed supplementation of an alfalfa silage-based diet compared with a control without added oilseed (Ward et al., 2002). In contrast, supplementation of a hay-based $\operatorname{diet}(\mathrm{F}: \mathrm{C}=$ 60:40) with EL had no effect on milk protein content (Egger et al., 2007), although negative effects of EL or ER supplementations on milk protein content have been reported in high-forage diets $(\mathrm{F}: \mathrm{C}>50: 50)$ based on corn silage or corn and grass silage (40:60) mixtures (Bayourthe et al., 2000; Gonthier et al., 2005; Akraim 

fed different oilseed supplements during indoor and outdoor periods

\begin{tabular}{|c|c|c|c|c|c|c|c|c|c|c|c|c|c|c|}
\hline \multirow[b]{3}{*}{ Item } & \multicolumn{7}{|c|}{ Indoor period $^{2}$} & \multicolumn{7}{|c|}{ Outdoor period ${ }^{3}$} \\
\hline & \multicolumn{5}{|c|}{ Treatment ${ }^{4}$} & \multirow[b]{2}{*}{ SEM } & \multirow{2}{*}{$\frac{P \text {-value }}{\text { Treatment }}$} & \multicolumn{5}{|c|}{ Treatment $^{4}$} & \multirow[b]{2}{*}{ SEM } & \multirow{2}{*}{$\frac{P \text {-value }}{\text { Treatment }}$} \\
\hline & CTL & EL & ER & FRM & WR & & & CTL & EL & ER & FRM & WR & & \\
\hline Total DMI $(\mathrm{kg} / \mathrm{d})$ & $1.6^{\mathrm{bc} *}$ & $0.8^{\mathrm{c} *}$ & $2.5^{\mathrm{ab} *}$ & $3.7^{\mathrm{a} *}$ & $3.4^{\mathrm{a} *}$ & 0.47 & $<0.001$ & & & & & & & \\
\hline $\begin{array}{l}\text { Milk yield }(\mathrm{kg} / \mathrm{d}) \\
\text { Milk fat }\end{array}$ & $2.5^{\mathrm{b} *}$ & $3.7^{\mathrm{ab} *}$ & $6.1^{\mathrm{a} *}$ & $6.1^{\mathrm{a} *}$ & $1.9^{\mathrm{b} *}$ & 1.01 & 0.02 & $2.9^{*}$ & $2.7^{*}$ & 1.6 & $2.8^{*}$ & $1.9^{*}$ & 0.85 & 0.81 \\
\hline $\begin{array}{l}\text { Content }(\%) \\
\text { Yield }(\mathrm{g} / \mathrm{d}) \\
\text { Milk protein }\end{array}$ & $-0.25^{\mathrm{bc} *}$ & $\begin{array}{l}-0.39^{\mathrm{c} *} \\
23^{\mathrm{b}}\end{array}$ & $\begin{array}{l}-0.54^{\mathrm{c} *} \\
28^{\mathrm{b}}\end{array}$ & $\begin{array}{c}0.15^{\mathrm{a}} \\
268^{\mathrm{a} *}\end{array}$ & $\begin{array}{l}0.02^{\mathrm{ab}} \\
70^{\mathrm{b}}\end{array}$ & $\begin{array}{l}0.131 \\
58.0\end{array}$ & $\begin{array}{r}<0.01 \\
0.01\end{array}$ & $\begin{array}{l}-0.26^{*} \\
19\end{array}$ & $\begin{array}{c}0.01 \\
102^{*}\end{array}$ & $\begin{array}{l}0.01 \\
54\end{array}$ & $\begin{array}{c}0.15 \\
131^{*}\end{array}$ & $\begin{array}{l}0.12 \\
97^{*}\end{array}$ & $\begin{array}{l}0.116 \\
37.1\end{array}$ & $\begin{array}{l}0.13 \\
0.26\end{array}$ \\
\hline $\begin{array}{l}\text { Content }(\%) \\
\text { Yield }(\mathrm{g} / \mathrm{d}) \\
\text { Milk lactose }\end{array}$ & $\begin{array}{l}-0.06^{\mathrm{ab}} \\
50^{\mathrm{b}} *\end{array}$ & $\begin{array}{l}-0.16^{\mathrm{b} *} \\
57^{\mathrm{b} *}\end{array}$ & $\begin{array}{c}0.10^{\mathrm{a}} \\
199^{\mathrm{a} *}\end{array}$ & $\begin{array}{c}0.01^{\mathrm{a}} \\
164^{\mathrm{a} *}\end{array}$ & $\begin{array}{c}0.02^{\mathrm{a}} \\
57^{\mathrm{b} *}\end{array}$ & $\begin{array}{l}0.056 \\
25.0\end{array}$ & $\begin{array}{c}0.04 \\
<0.001\end{array}$ & $\begin{array}{c}-0.03^{\mathrm{ab}} \\
74^{*}\end{array}$ & $\begin{array}{l}-0.11^{\mathrm{b} *} \\
66^{*}\end{array}$ & $\begin{array}{l}0.08^{\mathrm{a}} \\
63^{*}\end{array}$ & $\begin{array}{c}0.09^{\mathrm{a}} \\
106^{*}\end{array}$ & ${ }^{0.14^{*}}{ }^{\mathrm{a} *}$ & $\begin{array}{l}0.058 \\
25.1\end{array}$ & $\begin{array}{l}0.04 \\
0.75\end{array}$ \\
\hline Content $(\%)$ & -0.07 & 0.07 & 0.01 & 0.06 & 0.00 & 0.042 & 0.15 & 0.02 & 0.01 & -0.07 & -0.01 & 0.00 & 0.049 & 0.86 \\
\hline Yield (g/d) & $102^{\mathrm{b} *}$ & $208^{\mathrm{ab} *}$ & $308^{\mathrm{a} *}$ & $318^{\mathrm{a} *}$ & $90^{\mathrm{b*}}$ & 54.9 & 0.01 & $140^{*}$ & $137^{*}$ & 64 & $140^{*}$ & $93^{*}$ & 45.0 & 0.77 \\
\hline $\mathrm{BW}^{5}(\mathrm{~kg})$ & $28^{\mathrm{b} *}$ & $29^{\mathrm{b}} *$ & $62^{\mathrm{a} *}$ & $55^{\mathrm{a} *}$ & $51^{\mathrm{ab} *}$ & 8.5 & 0.05 & $22^{*}$ & $25^{*}$ & $44^{*}$ & $61^{*}$ & $32^{*}$ & 11.1 & 0.09 \\
\hline BW change ${ }^{6}(\mathrm{~kg})$ & -1 & -3 & -4 & -7 & 2 & 8.5 & 0.95 & 6 & 10 & 24 & 14 & -1 & 12.0 & 0.75 \\
\hline $\operatorname{BCS}(0-5)^{7}$ & $-0.5^{*}$ & -0.2 & -0.4 & -0.2 & -0.3 & 0.16 & 0.81 & -0.3 & -0.4 & -0.2 & -0.4 & -0.1 & 0.22 & 0.89 \\
\hline $\begin{array}{l}\text { BCS change }{ }^{6} \\
\text { Balances }^{8}\end{array}$ & -0.2 & -0.2 & 0.2 & -0.3 & 0.1 & 0.16 & 0.31 & 0.1 & -0.2 & $0.5^{*}$ & 0.1 & 0.1 & 0.14 & 0.08 \\
\hline $\begin{array}{l}\text { Energy } \\
\text { (MJ of net energy/d) }\end{array}$ & $2.6^{\mathrm{b}}$ & $0.1^{\mathrm{b}}$ & $6.2^{\mathrm{ab}}$ & $-6.8^{\mathrm{b}}$ & $15.7^{\mathrm{a} *}$ & 4.33 & 0.01 & & & & & & & \\
\hline $\mathrm{PDI}^{9}(\mathrm{~g} / \mathrm{d})$ & $-68^{\mathrm{a}}$ & $-278^{\mathrm{b} *}$ & $-242^{\mathrm{ab} *}$ & $-66^{\mathrm{a}}$ & $-91^{\mathrm{a}}$ & 60.4 & 0.02 & & & & & & & \\
\hline
\end{tabular}

${ }^{\mathrm{a}-\mathrm{C}}$ Means within a row with different superscript letters differ at $P<0.05$.

${ }^{1}$ Year 2 minus year 1.

${ }^{2}$ Week 10 to 16 of lactation, grass silage and hay-based diet.

${ }^{3}$ Calendar wk 30 to 36 , pasture-based diet.

${ }^{4}$ Cows fed no oilseed supplement $(\mathrm{CTL}, \mathrm{n}=7)$, or 2.5 to $5.0 \%$ of oil in diet DM from extruded linseed $(\mathrm{EL}, \mathrm{n}=8)$, extruded rapeseed $(\mathrm{ER}, \mathrm{n}=4)$, cold-pressed fat-rich rapeseed meal (FRM, $\mathrm{n}=8$ ), or whole unprocessed rapeseed ( $\mathrm{WR}, \mathrm{n}=8$ ).

${ }^{5}$ Measured every 2 wk.

${ }^{6}$ Inter-year difference of BW change and BCS change, measured between wk 10 and 16 of lactation (indoor period) and between calendar wk 30 and 36 (outdoor period).

${ }^{7}$ Recorded every $4 \mathrm{wk}$

${ }^{8}$ Balance $=$ intake minus requirements for maintenance and production, calculated according to INRA (2007a).

${ }^{9}$ True protein truly digestible in the small intestine (INRA, 2007a).

* Mean different from 0 at $P<0.05$. 
et al., 2007; Ferlay et al., 2010). The physiological mechanisms responsible for the reduction in milk protein content during lipid supplementation are not fully understood, but they could result from a dilution effect because lipid supplementation often increases milk production without changing protein yield (Chilliard and Ferlay, 2004; Schroeder et al., 2004). In the present study, milk and protein yields were not changed by EL or ER.

During the indoor period, treatment effects on DMI were dependent on the nature of oilseed because EL, but not ER, decreased forage intake and tended to decrease DMI. However, neither EL nor ER affected energy intake or milk yield (Tables 3 and 4). Collomb et al. (2004) found that cows receiving hay-based diets supplemented with $2.0 \%$ oil in the diet DM from ground linseed had lower DMI than cows receiving $2.5 \%$ oil in the diet DM from ground rapeseed. Furthermore, EL supplementation (5.7\% oil in the diet DM) of a corn silage-based diet (Chilliard et al., 2009) has been shown to decrease DMI, whereas ER supplementation (2.0\% oil in the diet DM) did not decrease DMI (Bayourthe et al., 2000). However, no effect of EL supplementation on forage intake or DMI was observed with a diet based on a grass silage and corn silage (60:40) mixture (4.7\% oil in the diet DM; Gonthier et al., 2005) or with a hay-based diet $(2.4 \%$ oil in the diet DM; Egger et al., 2007). The trend for EL to decrease DMI in this and several other studies is probably not due to lower diet digestibility because digestibility was not changed by EL in other studies (Gonthier et al., 2004; Doreau et al., 2009), and changes of BW and BCS did not differ among CTL, EL, and ER (Table 4). This trend could be due to postabsorptive effects of PUFA from EL, as suggested by decreases in DMI of cows receiving postruminal infusions of PUFA-rich oils (Shingfield et al., 2010). The physiological mechanisms responsible for the decrease in DMI mediated by circulating PUFA are not fully understood but could be related to secretion of hypophagic gut peptides, modulation of liver FA oxidation, or changes in neural stimulation of satiety centers (Allen et al., 2009). In our experiment, despite a trend for a negative effect on total DMI, EL supplementation had no effect on calculated energy balance, changes in BW and BCS, or plasma metabolite and insulin concentrations during the indoor period (Table 4), as has been observed by others during a 28 -wk supplementation with ground linseed (Petit and Côrtes, 2010).

Effects of Rapeseed Form (ER vs. FRM vs. $\boldsymbol{W R}$ ). Overall, WR did not affect milk yield during the first year of experimentation compared with CTL, ER, and FRM (Table 4). However, milk yield was significantly lower during $3 \mathrm{wk}$ of the outdoor period
(Figure 1A) for WR compared with FRM, leading to a numerical decrease in overall production. Similarly, supplementation with WR (2.0 to $4.9 \%$ oil in the diet DM) has been shown to decrease milk yield compared with ER, ground rapeseed, and rapeseed oil treatments in grass silage- or corn silage-based diets (Murphy et al., 1990; Bayourthe et al., 2000; Givens et al., 2009). In the present study, the calculated energy balance was positive for cows receiving WR but did not lead to increases in BW or BCS (Table 4), suggesting an inefficient use of the energy provided by WR. Negative effects of WR supplementation on milk yield could be explained by lower digestibility of the whole unprocessed rapeseeds (Murphy et al., 1990).

Effects of rapeseed supplementation on milk composition seemed to be dependent on the physical form of the seeds because only WR increased milk fat content during the outdoor period, without changing milk fat yield (Table 4). In contrast, others have observed a decrease in milk fat content when grazing cows were fed $600 \mathrm{~g} / \mathrm{d}$ of oil from ground or pelleted rapeseeds, without changes in milk fat yield (Lawless et al., 1998; Fearon et al., 2004). Therefore, these effects on milk fat content seem to be due to a dilution effect.

During the indoor period, rapeseed treatments decreased milk protein content without changing protein yield (Table 4). Decreases in milk protein content have been previously reported for grass silage-based diets supplemented with 3.4 or $5.8 \%$ oil in the diet DM from ground rapeseed (Aldrich et al., 1997; Ward et al., 2002), whereas supplementation with lower doses (2.6 or $2.8 \%$ oil in the diet DM) from ground rapeseed has not affected milk protein content (Murphy et al., 1990, 1995). During the indoor period, the decrease in milk protein content was more pronounced for FRM than for ER and WR, and during the outdoor period, only FRM significantly decreased milk protein content (Table 4). This effect could be partly because the diet content of additional fat provided by oilseed was higher for FRM than for ER or WR.

During the entire first year of experimentation, ER, FRM, and WR did not affect BW change or BCS change, plasma acetate, or glucose and insulin concentrations (Table 4), which is in agreement with previous long-term studies involving grass-based diets supplemented with ground rapeseed (Emanuelson et al., 1993; Ahlin et al., 1994).

\section{Second Year of Experimentation}

The increases in DMI, milk yield, and BW between yr 1 and 2 (Table 6) were due, at least in part, to the increase in the average parity of the herd. Effects of oilseed supplementation on milk yield and composition 
were identical between the first and second outdoor periods, except for milk protein content (Table 6). Grazing management and concentrate supplementation $(4.5 \mathrm{~kg} / \mathrm{d})$ and composition (Table 1) within each treatment were very similar for both outdoor periods. The repeatability and stability of rapeseed supplementation effects during grazing in 2 consecutive lactations are in agreement with previous studies involving ground, heat-treated rapeseed supplementation to a grass silagebased diet during 3 consecutive lactations (Emanuelson et al., 1993).

However, treatment effects differed between the first and the second indoor periods for DMI, milk yield and composition, and BW. This could be due in part to the higher concentrate proportion in the diet during the second indoor period and to differences in concentrate composition, which led to an increase in diet NFC and starch contents compared with the first indoor period. The increase in the diet NFC contents between the 2 indoor periods ranged between 4.8 and $11.1 \%$ of diet DM. Additionally, starch accounted for $43 \%$ of NFC for CTL and $<20 \%$ for other treatments during the first indoor period, whereas it was higher during the second indoor period $(57,59,49,37$, and $45 \%$ of NFC for CTL, EL, ER, FRM, and WR, respectively; Tables 3 and 5). Krause and Oetzel (2006) suggested that NFC should be limited to 35 to $40 \%$ of the diet DM when NFC is composed mainly of starch to prevent subacute ruminal acidosis and then avoid decreases in DMI and milk yield. Additionally, subacute ruminal acidosis is promoted when starch is rapidly fermentable (Firkins et al., 2001) and when concentrates are fed separately from forages (Krause and Oetzel, 2006). Therefore, the low DMI observed during the second indoor period for CTL and EL could be related to a possible decrease in ruminal $\mathrm{pH}$ due to NFC intake (35\% of the diet DM), which was composed mainly of fermentable starch (from wheat), and the distribution of concentrates in 2 meals/d. This could explain why CTL and EL induced smaller increases in milk yield and BW between the first and second indoor periods compared with ER and FRM. The increase in DMI observed for WR did not increase milk yield and was associated with a higher calculated energy balance compared with that of the other treatments. This suggests that energy provided by WR was not efficiently used, in agreement with results from the first indoor period (see the previous section).

Milk fat content and yield increased between the first and second indoor periods for FRM but decreased (content) or remained unchanged (yield) for CTL, EL, and ER. This could be explained in part by a greater starch content in diet DM during the second indoor period, which was more important for EL and ER than for FRM $(+15.3,+10.4$, and $+5.6 \%$ of the diet DM, respectively, compared with the first indoor period) because milk fat depression by oilseed supplementation depends on the starch level of the diet (Shingfield et al., 2010).

\section{CONCLUSIONS}

Results on milk yield and composition showed that long-term oilseed supplementation had persistent effects on cow performance within indoor and outdoor periods of the first year of experimentation and had repeatable effects between the 2 outdoor periods. Long-term effects observed over 2 consecutive lactations in this experiment were similar to those observed during short-term (1 to $3 \mathrm{mo}$ ) studies. Treatment effects depended on oilseed nature (rapeseed or linseed) and form (extruded seeds, cold-pressed fat-rich meal, or whole unprocessed seeds), and important interactions were observed between basal diet (preserved grass vs. pasture; starch content in the diet) and oilseed supplementation. Thus, during the first year of experimentation, WR increased milk fat content only during the outdoor period, and EL, ER, and WR decreased milk protein content only during the indoor period. Overall, substitution of fermentable carbohydrates with fat from linseed or rapeseed in grass-based diets did not improve dairy cow performance. Moreover, the depression of milk protein content induced by FRM and, to a lesser extent, by EL, $\mathrm{ER}$, and WR may affect milk prices and transformation yield. The interest in these supplementation strategies mainly results from their eventual availability in local markets and from the potential benefits associated with the putative positive modification of milk FA composition in a scenario of milk pricing systems that include FA composition.

\section{ACKNOWLEDGMENTS}

The authors thank M. Barbet and the team of the experimental unit Monts d'Auvergne of Orcival (INRA, UE1296) for feeding, milking, blood sampling, and care of cows, and M. Tourret, and P. Amblard (INRA, UR1213) for laboratory analyses. We thank Cetiom (Pessac, France) and ONIDOL (Organisation Nationale Interprofessionnelle des Graines et Fruits Oléagineux, Paris, France) for performing fat analyses and INZO $^{\circ}$ (Chateau Thierry, France) for performing starch analyses on concentrates. This research was supported in part by the European TRUEFOOD program (Traditional United Europe Food), an integrated project funded by the European Commission under the 6th Framework Program for RTD (contract no. FOODCT-2006-016264). In Vivo NSA, ONIDOL and ANRT 
(Association Nationale de la Recherche Technique) funded the PhD CIFRE (Convention Industrielle de Formation à la Recherche en Entreprise) fellowship of S. Lerch. We thank L. Delaby (INRA, UMR1348, StGilles, France), N. Friggens (INRA, UMR0791, Paris, France), and F. Glasser (INRA, UR1213) for helpful discussions on statistical analyses and model choice.

\section{REFERENCES}

Ahlin, K. A., M. Emanuelson, and H. Wiktorsson. 1994. Rapeseed products from double-low cultivars as feed for dairy cows-Effects of long-term feeding on thyroid-function, fertility and animal health. Acta Vet. Scand. 35:37-53.

Akraim, F., M. C. Nicot, R. Juaneda, and F. Enialbert. 2007. Conjugated linolenic acid (CLnA), conjugated linoleic acid (CLA) and other biohydrogenation intermediates in plasma and milk fat of cows fed raw or extruded linseed. Animal 1:835-843.

Aldrich, C. G., N. R. Merchen, J. K. Drackley, G. C. Fahey, and L. L. Berger. 1997. The effects of chemical treatment of whole canola seed on intake, nutrient digestibilities, milk production, and milk fatty acids of Holstein cows. J. Anim. Sci. 75:512-521.

Allen, M. S., B. J. Bradford, and M. Oba. 2009. Board-invited review: The hepatic oxidation theory of the control of feed intake and its application to ruminants. J. Anim. Sci. 87:3317-3334.

AOAC. 1997. Official Methods of Analysis. 16th ed. AOAC Int., Gaithersburg, MD.

Bayourthe, C., F. Enjalbert, and R. Moncoulon. 2000. Effects of different forms of canola oil fatty acids plus canola meal on milk composition and physical properties of butter. J. Dairy Sci. 83:690-696.

Brashear, A., and G. A. Cook. 1983. A spectrophotometric, enzymatic assay for D-3-hydroxybutyrate that is not dependent on hydrazine. Anal. Biochem. 131:478-482

Brouwer, I. A., A. J. Wanders, and M. B. Katan. 2010. Effect of animal and industrial trans fatty acids on HDL and LDL cholesterol levels in humans-A quantitative review. PLoS ONE 5:e9434.

Chilliard, Y., and A. Ferlay. 2004. Dietary lipids and forages interactions on cow and goat milk fatty acid composition and sensory properties. Reprod. Nutr. Dev. 44:467-492.

Chilliard, Y., C. Martin, J. Rouel, and M. Doreau. 2009. Milk fatty acids in dairy cows fed whole crude linseed, extruded linseed, or linseed oil, and their relationship with methane output. J. Dairy Sci. 92:5199-5211.

Collomb, M., H. Sollberger, U. Butikofer, R. Sieber, W. Stoll, and W. Schaeren. 2004. Impact of a basal diet of hay and fodder beet supplemented with rapeseed, linseed and sunflower seed on the fatty acid composition of milk fat. Int. Dairy J. 14:549-559.

Doreau, M., S. Laverroux, J. Normand, G. Chesneau, and F. Glasser. 2009. Effect of linseed fed as rolled seeds, extruded seeds or oil on fatty acid rumen metabolism and intestinal digestibility in cows. Lipids 44:53-62.

Egger, P., G. Holzer, S. Segato, E. Werth, F. Schwienbacher, G. Peratoner, I. Andrighetto, and A. Kasal. 2007. Effects of oilseed supplements on milk production and quality in dairy cows fed a hay-based diet. Ital. J. Anim. Sci. 6:395-405.

Emanuelson, M., K. A. Ahlin, and H. Wiktorsson. 1993. Long-term feeding of rapeseed meal and full-fat rapeseed of double low cultivars to dairy-cows. Livest. Prod. Sci. 33:199-214.

Fearon, A. M., C. S. Mayne, J. A. M. Beattie, and D. W. Bruce. 2004 Effect of level of oil inclusion in the diet of dairy cows at pasture on animal performance and milk composition and properties. J. Sci. Food Agric. 84:497-504.

Ferlay, A., B. Martin, S. Lerch, M. Gobert, P. Pradel, and Y. Chilliard. 2010. Effects of supplementation of maize silage diets with extruded linseed, vitamin $\mathrm{E}$ and plant extracts rich in polyphenols, and morning v. evening milking on milk fatty acid profiles in Holstein and Montbeliarde cows. Animal 4:627-640.
Firkins, J. L., M. L. Eastridge, N. R. St-Pierre, and S. M. Noftsger. 2001. Effects of grain variability and processing on starch utilization by lactating dairy cattle. J. Anim. Sci. 79:E218-E238.

Givens, D. I., K. E. Kliem, D. J. Humphries, K. J. Shingfield, and R. Morgan. 2009. Effect of replacing calcium salts of palm oil distillate with rapeseed oil, milled or whole rapeseeds on milk fattyacid composition in cows fed maize silage-based diets. Animal 3:1067-1074

Glasser, F., A. Ferlay, and Y. Chilliard. 2008. Oilseed lipid supplements and fatty acid composition of cow milk: A meta-analysis. J. Dairy Sci. 91:4687-4703.

Gobert, M., B. Martin, A. Ferlay, Y. Chilliard, B. Graulet, P. Pradel, D. Bauchart, and D. Durand. 2009. Plant polyphenols associated with vitamin $\mathrm{E}$ can reduce plasma lipoperoxidation in dairy cows given n-3 polyunsaturated fatty acids. J. Dairy Sci. 92:6095-6104.

Gonthier, C., A. F. Mustafa, R. Berthiaume, H. V. Petit, R. Martineau, and D. R. Ouellet. 2004. Effects of feeding micronized and extruded flaxseed on ruminal fermentation and nutrient utilization by dairy cows. J. Dairy Sci. 87:1854-1863.

Gonthier, C. A. F. Mustafa, D. R. Ouellet, P. Y. Chouinard, R. Berthiaume, and H. V. Petit. 2005. Feeding micronized and extruded flaxseed to dairy cows: Effects on blood parameters and milk fatty acid composition. J. Dairy Sci. 88:748-756.

Hoden, A., J. L. Peyraud, A. Muller, L. Delaby, and P. Faverdin. 1991. Simplified rotational grazing management of dairy-cows - Effects of rates of stocking and concentrate. J. Agric. Sci. 116:417-428.

INRA. 2006. PrevAlim-Version professionnelle intégrale. 3.23 ed. Educagri éditions, Theix, France.

INRA. 2007a. Alimentation des bovins, ovins et caprins. Besoins des Animaux: Valeur des aliments. Table INRA 2007. INRA, Versailles, France.

INRA. 2007b. INRAtion-Version professionnelle intégrale. 4.0 ed. Educagri editions, Theix, France.

INRA (Institut National de la Recherche Agronomique). 1981. Prévision de la Valeur Nutritive des Aliments des Ruminants. C. Demarquilly, ed. INRA Publications, Versailles, France.

Krause, K. M., and G. R. Oetzel. 2006. Understanding and preventing subacute ruminal acidosis in dairy herds: A review. Anim. Feed Sci. Technol. 126:215-236.

Lawless, F., J. J. Murphy, D. Harrington, R. Devery, and C. Stanton. 1998. Elevation of conjugated cis-9,trans-11-octadecadienoic acid in bovine milk because of dietary supplementation. J. Dairy Sci. $81: 3259-3267$.

Moss, A. 2002. The effects of long-term feeding of extracted rapeseed meal and whole rapeseed on the physical and financial performance, health and welfare of high yielding dairy cows. HGCA Project Report. Agriculture and Horticulture Development Board, Kenilworth, UK.

Murphy, J. J., J. F. Connolly, and G. P. McNeill. 1995. Effects on milk-fat composition and cow performance of feeding concentrates containing full-fat rapeseed and maize distillers grains on grasssilage based diets. Livest. Prod. Sci. 44:1-11.

Murphy, J. J., G. P. McNeill, J. F. Connolly, and P. A. Gleeson. 1990. Effect on cow performance and milk fat composition of including full fat soybeans and rapeseeds in the concentrate mixture for lactating dairy cows. J. Dairy Res. 57:295-306.

Neves, C. A., W. B. R. d. Santos, G. T. D. Santos, D. C. d. Silva C. C. Jobim, F. S. Santos, J. V. Visentainer, and H. V. Petit. 2009. Production performance and milk composition of dairy cows fed extruded canola seeds treated with or without lignosulfonate. Anim. Feed Sci. Technol. 154:83-92.

Petit, H. V. 2010. Review: Feed intake, milk production and milk composition of dairy cows fed flaxseed. Can. J. Anim. Sci. 90:115-127.

Petit, H. V., and C. Côrtes. 2010. Milk production and composition, milk fatty acid profile, and blood composition of dairy cows fed whole or ground flaxseed in the first half of lactation. Anim. Feed Sci. Technol. 158:36-43

Potts, T. J. 1967. Colorimetric determination of urea in feeds (report of AOAC Committee). J. AOAC Int. 50:56-58. 
Prolea. 2009. De la production à la consummation, France, Europe, Monde. Statistiques des oléagineux et protéagineux, huiles et protéines végétales, 2008-2009. Prolea, Paris, France.

SAS Institute. 2003. SAS/STAT User's Guide. SAS Institute Inc., Cary, NC.

Schroeder, G. F., G. A. Gagliostro, F. Bargo, J. E. Delahoy, and L. D. Muller. 2004. Effects of fat supplementation on milk production and composition by dairy cows on pasture: A review. Livest. Prod. Sci. 86:1-18.

Shingfield, K. J., L. Bernard, C. Leroux, and Y. Chilliard. 2010. Role of trans fatty acids in the nutritional regulation of mammary lipogenesis in ruminants. Animal 4:1140-1166.
Shingfield, K. J., Y. Chilliard, V. Toivonen, P. Kairenius, and D. I. Givens. 2008. Trans fatty acids and bioactive lipids in ruminant milk. Pages 3-65 in Bioactive Components of Milk. Vol. 606. Springer-Verlag Berlin, Berlin, Germany.

Van Soest, P. J., J. B. Robertson, and B. A. Lewis. 1991. Methods for dietary fiber, neutral detergent fiber, and nonstarch polysaccharides in relation to animal nutrition. J. Dairy Sci. 74:3583-3597.

Veissier, I. 1999. Animal experimentation: Biological, ethical and legislative elements. Prod. Anim. 12:365-375.

Ward, A. T., K. M. Wittenberg, and R. Przybylski. 2002. Bovine milk fatty acid profiles produced by feeding diets containing solin, flax and canola. J. Dairy Sci. 85:1191-1196. 